\title{
The Impact of Surgical Ventricular Restoration on Ischemic Mitral Regurgitation
}

\author{
Irena Butkuvienè, Loreta Ivaškevičienè \\ Clinic of Cardiovascular Diseases, Vilnius University, Lithuania
}

\begin{abstract}
Key words: mitral regurgitation; surgical ventricular repair.
\end{abstract}
Summary. Objective. The aim of current study was to evaluate and compare the changes in clinical status and mitral regurgitation $(M R)$ grade and long-term postoperative survival after left ventricle surgical restoration (SVR) operations.

Material and Methods. We retrospectively analyzed the data of 139 patients suffering from ischemic heart disease and left ventricular aneurysms or large akinesia, who underwent SVR and coronary artery bypass grafting without MR surgical correction between 1999 and 2006. The mean long-term postoperative follow-up was 3.6 years (SD, 3.0). Nine patients (6.5\%) died during the first 30 postoperative days.

Results. The mean MR grade during the long-term period increased significantly. The univariate logistic regression analysis showed that factors for the long-term mortality were age $(P=0.002)$, decompensation signs before $S V R(P=0.03)$, treatment with diuretics $(P=0.01), N Y H A$ functional class IV $(P=0.008)$, and moderate and severe $M R(P=0.04)$; however, multivariate logistic regression analysis demonstrated that only patient's age was an independent predictive factor $(P=0.004)$. $M R$ correction was found to be a significant prognostic factor of borderline significance for perioperative mortality $(P=0.05)$. The analysis of $M R$ grade (mild versus moderate versus severe) impact on long-term survival failed to demonstrate any association $(P=0.22)$.

Conclusions. Remodeling continued during the long-term period after SVR and CABG: there was an increase in the mean $M R$ degree. Left ventricular remodeling with moderate and severe $M R$ decreased survival rates during long-term period after surgical ventricular restoration; however, mitral regurgitation was not found to be an independent predictor of poor outcome.

\section{Introduction}

The lack of information has caused a number of discussions about the treatment strategies of ischemic mitral valve insufficiency, typical for remodeled left ventricle (LV) $(1,2)$. There is no consensus on the treatment of patients with ischemic heart disease (IHD) with LV dysfunction and mitral regurgitation (MR). The effectiveness of surgical ventricular restoration (SVR) in patients with depressed LV systolic function and mitral regurgitation is still being discussed $(3,4)$. According to Menicanti et al. (5), SVR reduces the size of the MV annulus, the distance between papillary muscles, and diastolic and systolic LV sphericity: when SVR was done without MV repair, in $87 \%$ of the cases, moderate and severe MR reduced to trivial or mild, and in $13 \%$ of the cases, it remained the same or increased later on. In a study by Shapira et al. (6), grade 1 and $2 \mathrm{MR}$ was left without surgical correction with expectations that after the revascularization of myocardium, it will remain stable or decrease; however, the results showed that untreated grade 1 and $2 \mathrm{MR}$ had a significant nega- tive impact on long-term survival. Yotsumoto et al. (7) also recommended surgical repair for mild MR. However, there are contrary opinions. A study by Paparella et al. (8) showed that grade 2 and $3 \mathrm{MR}$ was not a predictor of poor outcome. Paparella et al. and Mickleborough et al. $(8,9)$ reported that grade 2 and $3 \mathrm{MR}$ did not increase mortality risk during long-term follow-up after myocardial revascularization operations. These results were supported by Ryden et al. (10). According to Kaza et al. (11), an improvement in the degree of mitral insufficiency was documented in $60 \%$ of cases when SVR and coronary artery bypass graft (CABG) operations were performed without MR surgical correction. According to the authors, SVR results in a narrower configuration of papillary muscles and reduces MR. A study by Sartipy et al. (12) showed that only grade 3 and $4 \mathrm{MR}$ had a negative impact on longterm survival rates. The aim of our study was to evaluate how the grade of ischemic MR changed after SVR, to analyze long-term survival rates after SVR, and to investigate the relation between survival rates and MR grade.

Correspondence to I. Butkuvienè, Clinic of Cardiovascular Diseas- Adresas susirašinėti: I. Butkuvienė, VU Širdies ir kraujagyslių es, Vilnius University, Santariškių 2, 08661 Vilnius, Lithuania E-mail: Irena.Butkuviene@santa.lt ligu klinika, Santariškiu 2, 08661 Vilnius El. paštas: Irena.Butkuviene@santa.lt 


\section{Materials and Methods}

We analyzed the data of 139 consecutive patients suffering from IHD and LV aneurysms or large akinesia; these patients underwent SVR with or without CAGB and with or without MV surgical correction during the period from February 1999 to May 2006. The data were collected retrospectively, using medical case histories, outpatient records, and operation protocols. The patients' clinical condition and functional status, drug treatment, cardiovascular complications were evaluated on interview and physical examination. Echocardiographic examinations were performed preoperatively, during early period, after 6 months, and once a year during long-term follow-up after operation. This series included 119 male and 20 female patients $(85.6 \%$ and $14.4 \%$ ). The mean age was 60.5 years (SD, 10.6; range, 40-80 years). NYHA FC III-IV was diagnosed in 129 patients (92.8\%) preoperatively; the mean FC was 3.4 (SD, 0.6). Analysis of morphometry and function showed that the mean LV ejection fraction (EF) before SVR was 32.0\% (SD, $8.8 \%$, range, $12 \%-56 \%$ ); mean LV end systolic volume (ESV), $123.5 \mathrm{~mL}$ (SD, 52.6); mean end-systolic volume index (ESVI), $64.5 \mathrm{~mL} / \mathrm{m}^{2}$ (SD, 27.6); and mean LV end-diastolic dimension (EDD), 6.4 $\mathrm{cm}$ (SD, 0.8). The signs of heart decompensation were present in 53 patients $(39.6 \%)$ The mean angina pectoris (AP) score according to the Canadian classification was 3.1 (SD, 0.6). All the patients had a history of myocardial infarction (MI) (mean, 1.4; $\mathrm{SD}, 0.7)$. The mean duration from MI to operation was 67.1 months (SD, 69.6 months; range, 1 month to 26 years). Acute MI was diagnosed for 11 patients $(7.9 \%)$. The data of coronary angiography showed that the mean number of coronary artery (CA) affected was 2.4 (SD, 0.9) per patient. Eighty patients $(57.5 \%)$ had significant stenosis $(\geqslant 75 \%$ diameter $)$ of three CA; stenosis of the main left CA was observed in 19 operated patients $(13.7 \%)$. The aneurysms of anterior wall of LV and apex were present in 128 patients $(92.1 \%)$; in $11(7.9 \%)$ of the cases, there were aneurysms of inferior-posterobasal wall. Mild (grade 1) mitral regurgitation was diagnosed in 71 patients (51.1\%), moderate (grade 2) in $43(30.9 \%)$, and severe (grade 3 ) in 9 patients $(6.5 \%)$. Only 16 patients $(11.5 \%)$ had no mitral regurgitation. The mean MR grade was 1.3 (SD, 0.7). Primary arterial hypertension was diagnosed for 75 patients $(54.0 \%)$, and 25 patients $(18.0 \%)$ suffered from diabetes mellitus. Rhythm disturbances were documented in 33 study subjects (23.7\%): 18 (12.9\%) had paroxysmal ventricular tachycardia and 15 (10.8\%) suffered from paroxysmal atrial fibrillation or flutter.

A total of 138 patients (99.3\%) underwent cardiopulmonary bypass surgery and one off-pump procedure. In 132 cases (95.0\%), SVR was performed with concomitant CABG in order to achieve the completeness of revascularization. The mean number of distal anastomoses was 3.5 per patient (SD, 1.7; range, 0-8). The choice of surgical treatment was based on morphological and functional cardiac parameters. Endoventricular patch plasty was performed for 64 patients $(46.0 \%)$. The decision to plicate the LV wall was made in 12 cases $(8.6 \%)$. Extensive subendocardial scar resection was performed for 54 patients (38.8\%). During 29 operations $(20.8 \%)$, thromboses were removed from the LV cavity. Twenty patients (14.4\%) underwent MV repair (annuloplasty, valvuloplasty). Intraaortic counterpulsation was applied in 24 cases $(17.2 \%)$ because of marked LV insufficiency; 7 patients (5.0\%) required additional cardiopulmonary bypass and 24 patients (17.2\%) intravenous inotropic agents.

The long-term postoperative follow-up was performed for 111 (79.1\%) of the 139 patients. The follow-up duration of patients discharged for outpatient treatment ranged from 3 months to 7 years (mean follow-up, 3.6 years; SD, 3.0). Nine patients $(6.5 \%)$ died during the first 30 postoperative days. Twenty-six patients $(23.4 \%)$ discharged from the hospital had died during long-term follow-up. The fact of death was checked-up for all study subjects $(100 \%)$ and was confirmed by the Resident's Register Service at the Ministry of Interior of the Republic of Lithuania.

The patients after SVR and CABG were treated with ACE inhibitors, $\beta$-adrenoblockers, aspirin or indirect anticoagulants, diuretics, and statins. Mitral regurgitation was evaluated using color flow Doppler and continuous wave Doppler methods defining width, size, and velocity of the regurgitant jet in the left atrium (13), and the proximal isovelocity surface area (PISA) method was used (14). Regurgitant jet area (RJA) was obtained and divided by left atria area (LAA) measured in the same frame: RJA/ LAA <20\% (mild MR, grade 1), 20\%-40\% (moderate $\mathrm{MR}$, grade 2 ), and $>40 \%$ (severe MR, grade 3 ). Using the PISA method, MR was graded as mild and significant $<20 \mathrm{~mm}^{2}$ and $>20 \mathrm{~mm}^{2}$, respectively.

Data were analyzed using the SPSS 16.0 (version for Windows) software. Results were considered statistically significant when $P$ value was $\leqslant 0.05$.

\section{Results}

After one year following SVR and concomitant CABG (95.0\% of the cases), 108 patients (97.3\%) had no symptoms of AP. The mean AP class was 0.1 (SD, 0.3) one year after the operation $(P<0.001$, in comparison with the preoperative one), and there was an improvement during long-term follow-up $(P<0.001)$. The mean New York Heart Association (NYHA) functional class (FC) one year after surgery was 2.3 (SD, 0.4) (improved, $P<0.001$ ). The improvement in the mean NYHA FC was also recorded during the long-term follow-up (2.4 [SD, 
0.5] after 5 years; $P<0.001$, in comparison with the preoperative one). An improvement in LV EF was recorded as well: $\mathrm{LV} \mathrm{EF}$ was $37.5 \%$ (SD, 7.9\%) one year after the operation $(P<0.001)$. The decrease in LV EDD was observed after SVR. The mean LV EDD was $6.1 \mathrm{~cm}(\mathrm{SD}, 0.5)$ one year after the operation $(P<0.02)$; however, an increase in LV EDD was observed with time, and 3 years after the operation did not differ from the preoperative one (6.3 $\mathrm{cm}$ [SD, 0.5]; $P=0.52$ ). There was a decrease in the mean LV ESVI after SVR: one year after the operation, it was $53.7 \mathrm{~mL} / \mathrm{m}^{2}(\mathrm{SD}, 17.4)(P=0.015)$. The mean ESVI increased during the long-term followup and was $57.7 \mathrm{~mL} / \mathrm{m}^{2}$ (SD, 23.4) after 3 years ( $P=0.15$, in comparison with the preoperative one).

The changes in MR grade after SVR were assessed. The mean preoperative $\mathrm{MR}$ grade was 1.3 (SD, 0.7); one year after SVR, it was 1.0 (SD, 0.5) $(P=0.003)$. The mean $\mathrm{MR}$ grade during the longterm follow-up increased to 1.1 (SD, 1.4) (after 2 years), 1.2 (SD, 0.4) (after 3 years), and 1.3 (SD, 0.4 ) (after 4 years) and did not differ from the preoperative one $(P=0.48)$. The changes in MR grade in patients who underwent SVR without surgical correction of $\mathrm{MV}$ insufficiency were analyzed during the one-year period after the surgery. In order to examine the relationship between patient's functional class during one-year period after SVR and preoperative MR grade, the Fisher exact test was used. It was demonstrated that MR degree before the operation and patients postoperative NYHA FC were not related $(P=0.53)$. The mean $\mathrm{MR}$ grade decreased during one-year period after SVR $(P=0.003)$, and there was a decrease of the number of patients who had moderate or severe $\mathrm{MR}(P<0.01)$. However, the mean LV EDD, ESVI, and MR decreased during the one-year period after SVR, but thereafter, a gradual increase in these parameters was documented: 3-4 years after the operation, the mean LV EDD, LV ESVI, and MR became similar to the preoperative ones.

The 1-, 3-, 4-, 5-, and 6-year survival in this group was 90.6\% (SD, 2.5\%), 81.4\% (SD, 3.5\%), $76.0 \%$ (SD, 3.9\%), 69.8\% (SD, 4.5\%), and $62.8 \%$ (SD, 6.5\%), respectively. The univariate logistic regression model with one independent variable was used to predict the perioperative and long-term mortality by means of evaluating preoperative clinical, operative, and echocardiographic data (Table 1). The univariate logistic regression analysis revealed that duration of the illness $(P=0.005)$, NYHA FC IV $(P=0.043)$, rhythm disturbances $(P=0.03)$, MR surgical correction $(P=0.01), \quad L V \quad \mathrm{EF} \leqslant 20 \%$ $(P=0.002)$ were found to be significant predictors of perioperative mortality. The multivariate logistic regression model was employed to identify independent prognostic factors (Table 2). MR correction was found to be a significant prognostic factor

Table 1. Logistic Regression of the First 30-Day Mortality After Surgical Ventricular Restoration

\begin{tabular}{lccc}
\hline \multicolumn{1}{c}{ Factor } & $\begin{array}{c}\text { Regression Coefficient } \\
(\text { SD })\end{array}$ & $\begin{array}{c}\text { Odds Ratio } \\
(95 \% \text { CI })\end{array}$ & $\begin{array}{c}P \\
\text { value }\end{array}$ \\
\hline Age & $0.06(0.03)$ & $1.06(0.98 ; 1.13)$ & 0.09 \\
Gender (female vs. male) & $-5.63(109.7)$ & $0.001(0.001 ; 999.99)$ & 0.95 \\
AH (absent vs. present) & $-0.03(0.35)$ & $0.93(0.24 ; 3.63)$ & 0.92 \\
DM (absent vs. present) & $-0.14(0.41)$ & $0.75(0.14 ; 3.85)$ & 0.73 \\
Signs of decompensation prior operation (absent vs. present) & $-0.70(0.42)$ & $0.24(0.04 ; 1.30)$ & 0.09 \\
Duration of the illness & $0.01(0.004)$ & $1.10(1.003 ; 1.02)$ & 0.005 \\
NYHA FC II-III vs. IV & $-0.82(0.41)$ & $0.19(0.03 ; 0.95)$ & 0.043 \\
No. of CA with stenoses & $0.01(0.38)$ & $1.01(0.48 ; 2.14)$ & 0.96 \\
MR (no and grade 1 vs. grade 2 and 3) & $-0.64(0.36)$ & $0.27(0.06 ; 1.14)$ & 0.07 \\
Rhythm disturbances & $-0.75(0.35)$ & $0.22(0.05 ; 0.87)$ & 0.03 \\
MR correction & $-0.87(0.36)$ & $0.17(0.04 ; 0.72)$ & 0.01 \\
ES VI $\left(\leqslant 80\right.$ vs. $\left.>80 \mathrm{~mL} / \mathrm{m}^{2}\right)$ & $-0.51(0.42)$ & $0.35(0.06 ; 1.91)$ & 0.22 \\
LV EF $\leqslant 20 \%$ vs. $>20 \%$ & $1.26(0.42)$ & $12.50(2.40 ; 65.03)$ & 0.003 \\
LV EF $\leqslant 30 \%$ vs. $>30 \%$ & $0.48(0.34)$ & $2.62(0.67 ; 10.26)$ & 0.16 \\
\hline
\end{tabular}

AH, arterial hypertension; DM, diabetes mellitus; NYHA FC, New York Heart Association functional class; CA, coronary artery; $\mathrm{MR}$, mitral regurgitation; ES VI, end systolic volume index; LV EF, left ventricular ejection fraction.

Table 2. Multivariate Logistic Regression for Prediction of the First 30-Day Mortality

\begin{tabular}{|c|c|c|c|}
\hline Factor & $\begin{array}{l}\text { Regression Coeffi- } \\
\text { cient (SD) }\end{array}$ & $\begin{array}{l}\text { Odds Ratio } \\
(95 \% \text { CI })\end{array}$ & $P$ value \\
\hline Duration of the illness & $0.006(0.007)$ & $1.01(0.99 ; 1.02)$ & 0.43 \\
\hline Rhythm disturbances & $-0.62(0.58)$ & $0.29(0.2 ; 2.8)$ & 0.28 \\
\hline MR correction & $-1.09(0.56)$ & $0.11(0.01 ; 1.04)$ & 0.05 \\
\hline NYHA FC II-III vs. IV & $-0.12(0.73)$ & $0.78(0.05 ; 13.79)$ & 0.87 \\
\hline LV EF $\leqslant 20 \%$ vs. $>20 \%$ & $0.98(0.94)$ & $7.08(0.17 ; 288.5)$ & 0.30 \\
\hline
\end{tabular}

MR, mitral regurgitation; NYHA FC, New York Heart Association functional class; LV EF, left ventricular ejection fraction. 
of borderline significance for perioperative mortality $(P=0.05)$. Significant factors for prediction of long-term mortality were as follows: age $(P=0.002)$, decompensation signs before SVR $(P=0.03)$, treatment with diuretics before operation $(P=0.01)$, NYHA FC IV $(P=0.008)$, and moderate and severe $\operatorname{MR}(P=0.04)$ (Table 3$)$. It is important to note that analysis of $\mathrm{MR}$ impact on long-term survival using a logistic regression model (when comparison of odds ratio in patients without MR or with mild MR versus patients with moderate and severe $M R$ was performed) showed that the assessment of odds ratio was statistically significant $(P=0.04)$. However, the analysis of $\mathrm{MR}$ grade (mild versus moderate versus severe) impact on long-term survival using the chisquare or Fisher exact tests failed to demonstrate any association $(P=0.22)$. To evaluate $M R$ impact on long-term survival, the association between $\mathrm{MR}$ grade one year after SVR (grade 1 versus grade 2 and 3) and long-term survival using the Cox regression method was examined. No significant association was found $(\operatorname{Exp}(B)=2.48, P=0.13)$. In order to identify an independent predictor for worse outcome, a multivariate logistic regression model was developed (Table 4). Multivariate analysis revealed that only patient's age was an independent predictor of poor 6-year outcome $(P=0.004)$.

\section{Discussion}

Functional mitral regurgitation is a significant complication of highly developed left ventricular remodeling and heart failure, whose pathogenesis is multifactorial. It develops due to changes in the MV annulus - LV apparatus shape and volume geometry - leading to incomplete leaflet cooptation. In case of ischemic heart failure, it may also develop due to papillary muscles or lateral LV wall myocardial dysfunction. MV regurgitation in turn increases the volume overload of dilated LV, which results in MV annular dilatation, increasing LV wall tension, increasing MR degree, and progression of HF (15). Higher MV degree is associated with larger LV volumes, worse LV function, and lower patient survival rates: MR of any, even a mild, degree increased the mortality risk, and the increasing MR degree significantly raised the risk of cardiovascular events (16). Grigioni et al. (17) reported that ischemic MR, irrespective of LV volumes and dysfunction degree, was found to be an independent predictor of mortality during 5 years. However, Prucz et al. (4) provided evidence that the preoperative degree of MR was not related to long-term survival after SVR. Trichon et al. (18) showed that patients with HF often also had MR: of the 2057 patients with HF symptoms and LV EF $<40 \%, 56.2 \%$ were diagnosed with MR. MV insufficiency of any degree increased the mortality risk. MR can be eliminated by decreasing LV endsystolic volume and sphericity - SVR, reconstructing the MV annulus (by undersizing annuloplasty), by myocardial revascularization, and removing myocardial ischemia surrounding the MV apparatus. According to Yotsumuto et al. (7), the development

Table 3. Logistic Regression for Prediction of Long-Term Mortality

\begin{tabular}{lccc}
\hline \multicolumn{1}{c}{ Factor } & Regression coefficient (SD) & Odds ratio (95\% CI) & $P$ value \\
\hline Age & $0.07(0.02)$ & $1.07(1.02 ; 1.2)$ & 0.002 \\
Gender (female vs. male) & $-0.03(0.30)$ & $0.94(0.28 ; 3.1)$ & 0.92 \\
AH (absent vs. present) & $0.05(0.21)$ & $1.1(0.47 ; 2.58)$ & 0.81 \\
DM (absent vs. present) & $0.13(0.29)$ & $0.3(0.40 ; 4.20)$ & 0.66 \\
Signs of decompensation before operation (absent vs. present) & $-0.46(0.22)$ & $0.39(0.16 ; 0.93)$ & 0.03 \\
Treatment using diuretics (no vs. yes) & $-0.57(0.23)$ & $0.31(0.12 ; 0.77)$ & 0.01 \\
Duration of the illness & $0.004(0.003)$ & $1.005(0.99 ; 1.01)$ & 0.13 \\
NYHA FC II-III vs. IV & $-0.59(0.22)$ & $0.30(0.12 ; 0.73)$ & 0.008 \\
No. of CA with stenosis & $0.07(0.24)$ & $1.08(0.673 ; 1.73)$ & 0.75 \\
LV EF \& 20\% vs. > 20\% & $-0.02(0.56)$ & $0.95(0.10 ; 8.88)$ & 0.96 \\
No MR and grade 1 vs. grade 2 and 3 & $-0.43(0.22)$ & $0.41(0.17 ; 0.99)$ & 0.04 \\
Rhythm disturbances & $-0.02(0.26)$ & $0.951(0.34 ; 2.64)$ & 0.92 \\
MR correction & $0.07(0.34)$ & $1.156(0.30 ; 4.38)$ & 0.83 \\
\hline
\end{tabular}

AH, arterial hypertension; DM, diabetes mellitus; NYHA FC, New York Heart Association functional class; CA, coronary artery; LV EF, left ventricular ejection fraction; MR, mitral regurgitation.

Table 4. Multivariate Logistic Regression for Prediction of Long-Term Mortality

\begin{tabular}{lccc}
\hline \multicolumn{1}{c}{ Factor } & Regression coefficient (SD) & Odds ratio (95\% CI) & $P$ value \\
\hline Age & $0.08(0.03)$ & $1.097(1.02 ; 1.15)$ & 0.004 \\
Signs of decompensation & $-0.23(0.39)$ & $0.622(0.13 ; 2.93)$ & 0.55 \\
Diuretics & $-0.42(0.42)$ & $0.426(0.08 ; 2.07)$ & 0.38 \\
NYHA FC II, III, and IV & $-0.11(0.31)$ & $0.793(0.23 ; 2.74)$ & 0.71 \\
MR (no and grade 1 vs. grade 2 and 3) & $0.12(0.44)$ & $1.27(0.22 ; 7.1)$ & 0.78 \\
\hline
\end{tabular}

NYHA FC, New York Heart Association functional class; MR, mitral regurgitation. 
of late MR was associated with LV remodeling before SVR and larger LV volumes. SVR eliminates the damaged part of the LV myocardium; however, newly formed LV with damaged myocardium and structural extracellular matrix impairment, caused by preoperative remodeling, results in further LV remodeling (19). MR augments dilated LV volume overload, which in turn leads to MV annular dilatation, increasing LV wall tension, and progression of HF (15). Amigoni et al. (16) reported that higher MR degree was found to be associated with larger LV volumes, worse LV functioning, and worse survival rates. Similar results were provided by Grigioni et al. (17): a significant association between regurgitant volume and survival rates of patients with HF during 5-year period was revealed. Trichon et al. (18) showed that patients with HF often had $\mathrm{HF}$, and MR of any degree increased the mortality risk. However, Menicanti et al. (5) pointed out that for the majority of patients with MR, who had not undergone MV repair, it decreased to trivial or mild degree after SVR and CABG. On contrary, Paparella et al. (10) showed that grade 2 and $3 \mathrm{MR}$ did not increase the mortality risk during the period of 10 years. According to Mickleborough et al. (9), Ryden et al. (10), Prucz et al. (4), Mihaljevic et al. (20), and Kang et al. (1), MR did not increase the mortality risk during follow-up, when patients underwent myocardial revascularization. The RESTORE group performed SVR for 1198 patients, and in 23\% of cases, surgical correction for MR was performed concomitantly (21). The 30-day mortality was significantly higher after MR surgery but there was no significant difference in the survival rates between the two groups during the 5-year period, and MR was not found to be an independent predictor of late mortality. Lee et al. (22) supported the opinion that MR degree was not associated with long-term survival after SVR. Menicanti et al. (23) suggested that SVR, performed with or without CABG and with or without MV surgery, significantly reduced LV volumes and improved LV EF; however, a significant increase in LV volumes and MR degree was observed afterward. Grade 2 and higher MR did not increase in-hospital mortality risk and became a significant factor of higher mortality risk only when associated with restrictive diastolic dysfunction.

An association between MR degree and FC dur- ing the one-year period after SVR and survival after surgery was evaluated. According to the results of our study, MR grade after SVR decreased from 1.3 $(\mathrm{SD}, 0.7)$ to $1.0(\mathrm{SD}, 0.5)$ during the one-year period $(P=0.003)$. For the patients, who did not undergo $M V$ repair during the operation, the degree of MR decreased; during the first year after SVR, the number of patients having mild MR was increased: there were no patients with grade $3 \mathrm{MR}$, the percentage of patients with grade $2 \mathrm{MR}$ decreased from $30.9 \%$ to $10.8 \%$, and the proportion of patients with grade $1 \mathrm{MR}$ increased from $51.1 \%$ to $79.3 \%(P<0.05)$. According to our results, no association between $\mathrm{MR}$ degree before SVR and patient's NYHA FC one year after SVR was found $(P=0.53)$. Analysis of MR degree (mild versus moderate versus severe) impact on long-term survival demonstrated that there was no significant association $(P=0.22)$. In addition, our results showed that there was no relationship between MR grade, diagnosed during one year after SVR, and long-term survival $(P=0.13)$. However, the analysis of $\mathrm{MR}$ impact on long-term survival when comparison of odds ratio in patients without MR or with mild MR versus patients with moderate and severe MR was performed showed that the assessment was statistically significant $(P=0.04)$ : moderate and severe MR increased the likelihood of poor outcome during long-term period after SVR. It seems that LV remodeling, associated with MR, has a greater impact on long-term survival than MR degree. During the late postoperative period, mean MR grade, LV EDD, and LV ESVI were increased, and this confirms the development of further remodeling.

\section{Conclusions}

Remodeling continued during the long-term period after surgical ventricular restoration and coronary artery bypass grafting: there was an increase in the mean mitral regurgitation degree. Left ventricular remodeling with moderate and severe mitral regurgitation decreased survival rates during the long-term periods after surgical ventricular restoration; however, mitral regurgitation was not found to be an independent predictor of poor outcome.

\section{Statement of Conflict of Interest}

The authors state no conflict of interest.

\title{
Kairiojo skilvelio tūrio ir formos atkūrimo operacijų įtaka išeminiam dviburio vožtuvo nesandarumui
}

\author{
Irena Butkuvienė, Loreta Ivaškevičienè \\ Vilniaus universiteto Širdies ir kraujagysliu ligu klinika
}

Raktažodžiai: dviburio vožtuvo nesandarumas, kairiojo skilvelio tūrio ir formos atkūrimo operacijos.

Santrauka. Tyrimo tikslas. İvertinti išeminio dviburio vožtuvo nesandarumo laipsnio (DVN) kitimą po kairiojo skilvelio tūrio ir formos atkūrimo operacijų, ligonių išgyvenimą vèlyvuoju pooperaciniu laikotarpiu bei išgyvenimo ryšį su DVN laipsniu. 
Tyrimo medžiaga ir metodai. Atlikome retrospektyvųii 139 sergančiųiu išemine širdies liga su kairiojo skilvelio aneurizmomis ir plačiomis akinezėmis tūrio ir formos atkūrimo operacijų, atliktų 1999-2006 m., tyrimą. Vidutinè stebėsenos po operacijos trukmé -3,6 (SN, 3,0) metai. Devyni operuotieji $(6,5$ proc.) mirẻ per pirmąsias 30 parų.

Rezultatai. Pirmaisiais metais po operacijos sumažejęs vidutinis dviburio vožtuvo nesandarumo laipsnis reikšmingai didèjo vėlyvuoju laikotarpiu. Vienalypès logistinès regresijos analizė parodė, kad vèlyvuoju pooperaciniu laikotarpiu mirštamumo prognoziniai rodikliai yra amžius $(p=0,002)$, dekompensacijos požymiai prieš operaciją $(p=0,03)$, gydymas diuretikais $(p=0,01)$, NYHA IV FK $(p=0,008)$, II ir III ${ }^{\circ}$ mitralinio vožtuvo nesandarumas $(\mathrm{p}=0,04)$, bet daugialypès logistinès regresijos duomenimis, tik amžius yra nepriklausomas prognozinis rodiklis $(\mathrm{p}=0,004)$. Daugialypès logistinès regresijos analizè parodè, kad dviburio vožtuvo nesandarumo korekcija yra nepriklausomas pirmųiu 30 parų mirštamumo veiksnys $(p=0,05)$. Dviburio vožtuvo nesandarumo laipsnio (I, II, III) įtakos ilgalaikiam išgyvenamumui išaiškinti taikėme Fischerio tikslųi testą. Patikimos priklausomybès nenustatyta $(\mathrm{p}=0,22)$.

Išvados. Remodeliacijos procesas vèlyvuoju laikotarpiu po kairiojo skilvelio tūrio ir formos atkūrimo operacijos ir revaskulizacijos tęsėsi: didejo vidutinis dviburio vožtuvo nesandarumo laipsnis. Kairiojo skilvelio remodeliacija ir dviburio vožtuvo II-III ${ }^{\circ}$ nesandarumas reikšmingai mažina išgyvenamumą po kairiojo skilvelio tūrio ir formos atkūrimo operacijų.

\section{References}

1. Kang DH, Kim MJ, Kang SJ, Song JM, Song H, Hong MK, et al. Mitral valve repair versus revascularization alone in the treatment of ischemic mitral regurgitation. Circulation 2006;114(1 Suppl):I499-503.

2. Gillinov AM. Is ischemic mitral regurgitation an indication for surgical repair or replacement? Heart Fail Rev 2006;11:231-9.

3. Lancellotti P, Marvick T, Pierard LA. How to manage ischaemic mitral regurgitation. Heart 2008;94:1497-502.

4. Prucz RB, Weiss ES, Patel ND, Nwakanma LU, Shah AS, Conte JV, et al. The impact of surgical ventricular restoration on mitral valve regurgitation. Ann Thorac Surg 2008; 86:726-34.

5. Menicanti L, Di Donato M, Castelvecchio S; RESTORE Group. Functional ischemic mitral regurgitation in anterior ventricular remodeling: results of surgical ventricular restoration with and without mitral repair. Heart Fail Rev 2004;9:317-27.

6. Shapira OM, Hunter CT, Anter E, Bao Y, DeAndrade K, Lazar HL, et al. Coronary artery bypass grafting in patients with severe left ventricular dysfunction - early and midterm outcomes. J Card Surg 2006;21:225-32.

7. Yotsumoto G, Sakata R, Ueno T, Iguro Y, Kinjo T, Kobayashi A, et al. Late development of mitral regurgitation after left ventricular reconstruction surgery. Ann Thorac Cardiovasc Surg 2005;11:159-63.

8. Paparella D, Mickleborough LL, Carson S, Ivanov J. Mild to moderate mitral regurgitation in patients undergoing coronary bypass grafting: effects on operative mortality and longterm significance. Ann Thorac Surg 2003;76:1094-100.

9. Mickleborough LL, Merchant N, Provost I, Carson S, Ivanov J. Ventricular reconstruction for ischemic cardiomyopathy. Ann Thorac Surg 2003;75:S6-12.

10. Ryden T, Bech-Hanssen O, Brandrup-Wognsen G, Nilsson F, Svensson S, Jeppsson A. The importance of grade 2 ischemic mitral regurgitation in coronary artery bypass grafting. Eur J Cardiothorac Surg 2001;20:276-81.

11. Kaza AK, Patel MR, Fiser SM, Long SM, Kern JA, Tribble $\mathrm{CG}$, et al. Ventricular reconstruction results in improved left ventricular function and amelioration of mitral insufficiency. Ann Surg 2002;6:828-32.

12. Sartipy U, Albage A, Lindblom D. Risk factors for mortality and hospital re-admission after surgical ventricular restoration. Eur J Cardiothorac Surg 2006;30:762-9.

13. Helmcke F, Nanda NC, Hsiung MC, Soto B, Adey CK, Goyal RG, et al. Color Doppler assessment of mitral regurgi- tation with orthogonal planes. Circulation 1987;75:175-83.

14. Zoghbi WA, Enriquez-Sarano M, Foster E, Grayburn PA, Kraft CD, Levine RA, et al. Recommendations for evaluation of the severity of native valvular regurgitation with two-dimensional and Doppler echocardiography. I Am Soc Echocardiography 2003;16:777-802.

15. Yiu HY, Su MY, Liao TY, Peng HH, Lin FY, Tseng WY. Functional mitral regurgitation in chronic ischemic coronary artery disease: analysis of geometric alterations of mitral apparatus with magnetic resonance imaging. J Thorac Cardiovasc Surg 2004;128(4):543-51.

16. Amigoni M, Meris A, Thune JJ, Mangalat D, Skali H, Bourgoun $\mathrm{M}$, et al. Mitral regurgitation in myocardial infarction complicated by heart failure, left ventricular dysfunction, or both: prognostic significance and relation to ventricular size and function. Eur Heart J 2007;28:326-33.

17. Grigioni F, Enriquez-Sarano M, Zehr KJ, Bailey KR, Tajik AJ. Ischemic mitral regurgitation. Long term outcome and prognostic implications with quantitative Doppler assessment. Circulation 2001;103:1759-64.

18. Trichon BH, Felker M, Shaw LK, Cabell CH, O'Connor $\mathrm{CM}$. Relation of frequency and severity of mitral regurgitation to survival among patients with left ventricular systolic dysfunction and heart failure. Am J Cardiol 2003;91:538-43.

19. Otsuji Y, Kuwahara E, Yuge K, Yotsumoto G, Ueno T, Nakashiki $\mathrm{T}$, et al. Relation of aneurysmectomy in patients with advanced left ventricular remodeling to postoperative left ventricular filling pressure, redilatation with ischemic mitral regurgitation. Am J Cardiol 2005;95:517-21.

20. Mihaljevic T, Lam BK, Rajeswaran I, Takagaki M, Lauer MS, Gillinov AM, et al. Impact of mitral valve annuloplasty combined with revascularization in patients with functional ischemic mitral regurgitation. I Am Coll Cardiol 2007; 49:2191-201.

21. Athanasuleas CL, Buckberg GD, Stanley AW, Siler W, Dor V, Di Donato M, et al.; the RESTORE Group. Surgical ventricular restoration in the treatment of congestive heart failure due to post-infarction ventricular dilatation. J Am Coll Cardiol 2004;44:1439-45.

22. Lee R, Hoecher K, McCarthy PM. Ventricular reconstruction surgery for congestive heart failure. Circulation 2004;101:61-71.

23. Menicanti L, Castelvecchio S, Ranucci M, Frigiola A, Santambrogio C, de Vincentiis C, et al. Surgical therapy for ischemic heart failure: single-centre experience with surgical anterior ventricular restoration. J Thorac Cardiovasc Surg 2007;134:433-41. 